\title{
OBECNOŚĆ ŻAKIEWICZA W LITERATUROZNAWSTWIE I PUBLICYSTYCE LITERACKIEJ (WYBÓR BIBLIOGRAFICZNY)
}

\author{
KATARZYNA WOJAN \\ Uniwersytet Gdański \\ Wydział Filologiczny \\ Instytut Skandynawistyki \\ Pracownia Leksykograficzno-Bibliograficzna \\ Neofilologia, ul. Wita Stwosza 51, 80-308 Gdańsk, Polska \\ e-mail: finkw@univ.gda.pl \\ ORCID: https://orcid.org/0000-0002-0368-727X \\ (nadesłano 11.07.2018; zaakceptowano 12.09.2018)
}

\section{Abstract \\ Żakiewicz's presence in literature and literary journalism (bibliographic selection)}

The study contains a list of 302 bibliographic items regarding the literary and scientific work of Zbigniew Żakiewicz, arranged according to genre and chronology.

\section{Key words}

Zbigniew Żakiewicz, Russian philologists, literary studies, literary journalism, bibliographies.

\section{Streszczenie}

Opracowanie zawiera wykaz 302 pozycji bibliograficznych dotyczących twórczości literackiej i naukowej Zbigniewa Żakiewicza, ułożonych w porządku genologicznym oraz chronologicznym. 


\section{Słowa kluczowe}

Zbigniew Żakiewicz, rusycyści, literaturoznawstwo, publicystyka literacka, bibliografie.

Niniejsze opracowanie zawiera 302 pozycje bibliograficzne dotyczące twórczości literackiej i naukowej Zbigniewa Żakiewicza. Wykaz został ułożony w porządku genologii publikacji z zachowaniem chronologii wydań. Na wybór składają się monografie książkowe, w tym kilka wieloautorskich (7 pozycji), publikacje w wydawnictwach zwartych oraz ciągłych, takie jak artykuły, rozdziały książek, recenzje i omówienia, szkice literackie i publicystyczne, wywiady literackie (obejmujące 285 pozycji), artykuły naukowe niepolskich autorów opublikowane za granicą (7 pozycji), numer specjalny periodyku akademickiego (1), polskie prace naukowe i dyplomowe, takie jak rozprawa doktorska (1 pozycja) oraz praca licencjacka (1 pozycja). Spośród monografii autorskich wyszczególnić należy trzy książki poświęcone dziełom pisarskim Żakiewicza, a mianowicie publikacje Od małej ojczyzny do Uniwersum: sacrum w twórczości Zbigniewa Żakiewicza Tatiany Czerskiej (2006), Pamięć, nostalgia, tożsamość. Kulturowe aspekty estetyki pogranicza w twórczości Zbigniewa Żakiewicza Macieja Dęboroga-Bylczyńskiego (2011) oraz Autobiograficzne świadectwa lektury: Żakiewicz, Jankowski, Kamieńska Anny Stempki (2012). Warto też dodać, iż ósma rocznica śmierci Pisarza została upamiętniona tegorocznym wydaniem specjalnym „Gazety Uniwersyteckiej: Pisma Społeczności Akademickiej Uniwersytetu Gdańskiego” opatrzonym tytułem: Zbigniew Żakiewicz. In memoriam i przygotowanym przez Katarzynę Wojan i Zbigniewa Kaźmierczyka.

Prezentowany wykaz stanowi istotne dopełnienie Bibliografii dorobku literackiego i naukowego Zbigniewa Żakiewicza przygotowanej przez Katarzynę Wojan i zamieszczonej w tomie drugim rocznika Studia Rossica Gedanensia (2015, s. 553-594).

\section{Wykaz bibliograficzny (wybór) ${ }^{1}$}

\section{Monografie - pozycje książkowe}

Wierciński, Adam (199). Głowy opolskie. Opole: Miejska Oficyna Wydawnicza.

Czerska, Tatiana (2006). Od małej ojczyzny do Uniwersum: sacrum w twórczości Zbigniewa Żakiewicza. Szczecin: Uniwersytet Szczeciński.

Dęboróg-Bylczyński, Maciej (2011). Pamięć, nostalgia, tożsamość: kulturowe aspekty estetyki pogranicza w twórczości Zbigniewa Żakiewicza. Bydgoszcz: Teatr Mały.

Czerska, Tatiana i Łozowska, Renata Katarzyna (red.) (2012). Czytanie Żakiewicza. Szczecin: Wydawnictwo Zapol.

Stempka, Anna (2012). Autobiograficzne świadectwa lektury: Żakiewicz, Jankowski, Kamieńska. Bydgoszcz: Wydawnictwo Uniwersytetu Kazimierza Wielkiego.

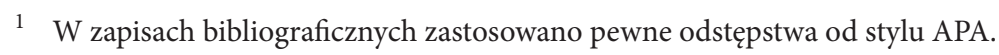


Wojan, Katarzyna (red.) (2017). W czasie zatrzymane. T. 2: Ze Zbigniewem Żakiewiczem na Kresach $i$ w bezkresie. Seria Biblioteka „Studia Rossica Gedanensia”. Gdańsk: Wydawnictwo Uniwersytetu Gdańskiego.

\section{Wydania specjalne periodyków}

Wojan, Katarzyna i Kaźmierczyk, Zbigniew (red.) (2018). „Gazeta Uniwersytecka. Pismo Społeczności Akademickiej Uniwersytetu Gdańskiego”. Wydanie specjalne: Zbigniew Żakiewicz. In memoriam (Gdańsk).

\section{Artykuły i rozdziały książek, recenzje i omówienia, szkice, wywiady}

Kolbuszewski, Jacek (1962). Zbigniew Żakiewicz: Chłopiec o lisiej twarzy. „Kwartalnik Opolski”, nr 3-4, s. 157-158 [recenzja].

Łukasiewicz, Jacek (1962). Chłopiec o lisiej twarzy. „Odra”, nr 10, s. 108-109 [recenzja]. Mencwel, Andrzej (1962). W cieniu patronatu. „Współczesność”, nr 17, s. 9 [recenzja]. Pochroń, Edward (1962). Chłopiec o lisiej twarzy. „Trybuna Opolska”, nr 118, s. 4 [recenzja].

Starowieyska-Morstinowa, Zofia (1962). Z notatnika recenzenta. „Tygodnik Powszechny", nr 28, s. 4 [recenzja].

Żabicki, Zbigniew (1962). „Na wpół smutnie, na wpół ironicznie... ”. (Cykl Rozmowy o debiutach). „Nowe Książki”, nr 17, s. 1058-1060 [recenzja].

Herbst, Lothar (1967). Świat dzieckiem podszyty. „Kultura”, nr 35, s. 5 [recenzja].

Kostaszuk, Krystyna (1967). Z kraju lat dziecinnych. „Nowe Książki”, nr 22, s. 13711372 [recenzja].

Misiorny, Michał (1967). Podróże w dzieciństwo. (Rubryka Pisarze i książki). „Głos Wybrzeża”, nr 221, s. 4 [recenzja].

Netz, Feliks (1967). „Liście”. „Poglądy”, nr 18, s. 15.

Nowicki, Krzysztof (1967). Szkice i zarysy: oś świata. Rubryka Nowości prozy. „Życie Literackie", nr 51, s. 10 [recenzja].

Skwarnicki, Marek (1967). Zbigniew Żakiewicz: „Liście”. „Tygodnik Powszechny”, nr 41, s. 6 [recenzja].

Zurakowski, Bogusław (1967). Wyobraźnia autentyczna. „Trybuna Opolska”, nr 119, s. 4 [recenzja].

Burek, Tomasz (1968). Kto będzie szalony? „Twórczość”, nr 7, s. 118-119 [recenzja].

Drawicz, Andrzej (1968). Niebo i ziemia. „Sztandar Młodych”, nr 103, s. 3 [recenzja].

Fornalczyk, Feliks (1968). Marzenia o sobie. „Fakty i Myśli”, nr 8, dod. literacki „Wiatraki”, nr 8, s. 2 [recenzja].

Jarosiński, Zbigniew (1968). Udręka pytań odwiecznych. „Kultura”, nr 18, s. 11 [recenzja].

Kazimierczyk, Barbara (1968). Żelazne ptaki nad zaściankiem. „Kierunki”, nr 25, s. 8 [recenzja].

Maciąg, Włodzimierz (1968). Konkretne i wzniosłe. (Rubryka Nowości prozy). „Życie Literackie", nr 29, s. 11 [recenzja].

Mańkowski, Jerzy (1968). Saga rodu Abaczów. „Nurt”, nr 9, s. 48 [recenzja].

Moskalówna, Ewa (1968). Tajemnica Abaczów. (Rubryka Książka miesiąca). „Litery”, nr 12, s. 35 [recenzja]. 
Porębski, Edward (1968). Z notatnika bibliofila: dzieje i mitologia. „Express Wieczorny", nr 123, s. 6 [recenzja].

Skwarnicki, Marek (1968). Zbigniew Żakiewicz: „Ród Abaczów”. „Tygodnik Powszechny", nr 19, s. 6 [recenzja].

Termer, Janusz (1968). Proza niedookreślenia. „Twórczość”, nr 3, s. 128-129 [recenzja]. Termer, Janusz (1968). „Szczęściarz”, „Jeszcze miłość... ”, „Ród Abaczów”. (Rubryka Współczesna proza polska). „Polonistyka”, nr 4-5, s. 106-109 [recenzja].

Ziątek, Zygmunt (1968). Ostatni z rodu. „Miesięcznik Literacki”, nr 9, s.139-140 [recenzja].

Żurakowski, Bogusław (1968). Liście. „Fama: Miesięcznik Studentów Opola”, nr 20-21, s. 15 [recenzja].

Chylicka, Wanda (1969). Abacze i Żubrowicze. „Więź”, nr 2-3, s. 187-193.

Kubicki, Bohdan (1969). Kłopoty i uroki wyobraźni: o prozie Zbigniewa Żakiewicza, „Litery”, nr 10, s. 5-7.

Burek, Tomasz (1971). Kto będzie szalony?. W: tegoż: Zamiast powieści. Warszawa: Czytelnik, s. 287-290.

Drawicz, Andrzej (1971). Rozszczepienie jaźni Zbigniewa Żakiewicza. „Sztandar Młodych", nr 22, s. 3.

Furnal, Irena (1971). Wycieczka przeciw Głowniowskim. „Miesięcznik Literacki”, nr 5, s. $125-126$ [recenzja].

Huzik, Władysław (1971). Biały karzeł. „Kierunki”, nr 7, s. 9 [recenzja].

Jodłowski, Marek (1971). Biała plama czyli powtórka z niesamowitości. „Opole”, nr 1, s. 25 [recenzja].

Kotlica, Jacek (1971). Nasz człowiek w rosyjskim pejzażu. „Fakty i Myśli”, nr 17, s. 7 [recenzja].

Kotlica, Jacek (1971). O karłach i olbrzymach. „Głos Wybrzeża”, nr 156, s. 6 [recenzja]. Ludzie i krajobrazy: rosyjskie pamiątki. Rubryka Książki - Nowości. „Kultura” 1971, nr 3, s. 9 [recenzja].

Łubieński, Tomasz (1971). Ciało i dusza. „Kultura” nr 14, s. 9 [recenzja].

Łukasiewicz, Jacek (1971). Zbigniew Żakiewicz: „Biały karzel”. „Tygodnik Powszechny", nr 28, s. 6 [recenzja].

Maciąg, Włodzimierz (1971). Wspomnienia, sny i coś z życia. (Rubryka Nowości prozy). „Życie Literackie”, nr 11, s. 10 [recenzja].

Mazurczyk, Jerzy (1971). Kłopoty z tożsamością: książki Wybrzeża. „7 [Siódmy] Głos Tygodnia", nr 17, s. 8 [recenzja].

Moskalówna, Ewa (1971). Człowiek w lustrze. „Litery”, nr s. 33 [recenzja].

Moskalówna, Ewa (1971). Pisarz i podróże. „Litery”, nr 4, s. 32-33 [recenzja].

Nowicki, Krzysztof (1971). Literatura bez grzechu. „Fakty i Myśli”, nr 2, s. 6 [recenzja].

Termer, Janusz (1971). Udręki świadomości. „Nowe Książki”, nr 9, s. 595-596 [recenzja].

Żurowski, Andrzej (1971). Fakty i mity. „Głos Wybrzeża”, nr 61, s. 6 [recenzja].

Bieńkowski, Zbigniew (1972). Rozkosze neurastenii. „Twórczość”, nr 7, s. 104-106 [recenzja].

Duda, Harry (1972). Ostatni najazd na Niżany. „Opole”, nr 6, s. 28 [recenzja]. 
Kiszkis, Andrzej (1972). Ską te ptaki? Cykl: Poddasza, pracownie. „Dziennik Bałtycki”, nr 55, s. 6 [recenzja].

Kobylińska-Masiejewska, Eugenia (1972). O pewnej dziwnej powieści. „Dziennik Bałtycki”, nr 240, s. 6 [recenzja].

Pochwała wyobraźni (1972). Rubryka Lektury na lato. „Literatura”, nr 25, s. 7 [recenzja].

Stiller, Robert (1972). Niezła potworkologia (z metodologia). „Nowe Książki”, nr 18, s. 53-56 [recenzja].

Śliwiński, Marian (1972). Kraina Sto Piątej Tajemnicy. „Litery”, nr 12, s. 34-35 [recenzja].

Termer, Janusz (1972). „Prozę Zbigniewa Żakiewicza...”. (Rubryka Współczesna proza polska). „Polonistyka”, nr 1, s. 54-58 [recenzja].

Żyłko, Bogusław (1972). „Ród Abaczów”: poetycki zapis świadomości. „Dziennik Bałtycki”, nr 13, s. 6 [recenzja].

Drwęcki, Andrzej (1973). Powieści Maciaga i Żakiewicza oraz inne książki. (Rubryka Księgi, książki, książeczki). „Nowa Szkoła”, nr 10, s. 65 [recenzja].

Duda, Harry (1973). Grawitacja wewnętrzna. „Opole”, nr 12, s. 28-29 [recenzja].

Niżyński, Wojciech (1973). Śnić siebie sobie. „Nowe Książki”, nr 23, s. 28-29 [recenzja].

Nowicki, Krzysztof (1973). Kto kogo śni. „Fakty”, nr 39, s. 6 [recenzja].

Paukszta, Eugeniusz (1973). To sen tylko, Danielu. „Głos Wielkopolski”, nr 208, s. 5 [nota].

Pysiak, Krzysztof K. (1973). Daniel w krainie czarów. [Brak danych] nr 40, s. 8 [recenzja].

Termer, Janusz (1973). Życie snem. „Trybuna Ludu”, nr 223, s. 6 [recenzja].

Wegner, Jacek (1973). Zabawa w sen. „Kultura”, nr 34, s. 9 [recenzja].

Woźniak, Marzena (1973). Skąd przychodzisz Danielu... „Litery”, nr 12, s. 36-37 [recenzja].

Żukrowski, Wojciech (1973). Kraina Sto Piątej Tajemnicy. „Trybuna Ludu”, nr 103, s. 7 [recenzja].

Brudnicki, Jan Z. (1974). Pod i ponad świadomością. „Tygodnik Kulturalny”, nr 12, s. 4 [recenzja].

Gostkowski, Stanisław (1974). Parabola ludzkiego losu. „Nowy Wyraz”, nr 6-7, s. 230-233 [recenzja].

Kuźma, Erazm (1974). Życie - snem. „Spojrzenia”, nr 8, s. 27 [recenzja].

Poradecki, Jerzy (1974). Zbigniewa Żakiewicza księga snów. „Odgłosy”, nr 37, s. 15 [recenzja].

Puzdrowski, Edmund (1974). Wieczne dziecko. „Twórczość”, nr 9, s. 118-120 [recenzja].

Termer, Janusz (1974). „Jestem autentystą...”. (Rubryka Współczesna proza polska). „Polonistyka”, nr 2, s. 44-46 [recenzja].

Bukowska, Anna (1975). Zejście w Dolinę. „Miesięcznik Literacki”, nr 12, s. 121-122 [recenzja].

Duda, Harry (1975). Dolina pamięci. „Opole”, nr 9, s. 28-29 [recenzja].

Hamerliński, Andrzej (1975). Poemat o miłości. „Tygodnik Kulturalny”, nr 24, s. 4 [recenzja]. 
Kazimierczyk, Barbara (1975). Dolina Hortensji. „Kierunki”, nr 20, s. 10 [recenzja].

Legut, Lucyna (1975). Przeczytałam książkę... (Cykl Różowe i czarne). „Dziennik Bałtycki”, nr 179, s. 1 [recenzja].

Nowicki, Krzysztof (1975). Poemat prozą. „Fakty”, nr 27, s. 6 [recenzja].

Orski, Mieczysław (1975). Ballada. „Twórczość”, nr 11, s. 107-108 [recenzja].

Pieszczachowicz, Jan (1975). Mit doliny miłości i śmierci. „Nowe Książki”, nr 15, s. 14-16 [recenzja].

Termer, Janusz (1975). „Ukazały się ostatnio...”. (Rubryka Współczesna proza polska). „Polonistyka”, nr 5, s. 40-43 [recenzja].

Borkowska, Ewa (1976). Niedojrzałość. „Czas”, nr 12, s. 23 [recenzja].

Hartwig-Sosnowska, Jolanta (1976). Dla maluchów. „Nowe Książki”, nr 24, s. 63-64 [recenzja].

Puzdrowski, Edmund (1976). Poznać siebie. „Nadodrze”, nr 4, s. 9 [recenzja].

Tarczałowicz, Jacek (1976). Przykuci do zmienności. „Życie Literackie”, nr 16, s. 15 [recenzja].

Duda, Harry (1977). W mądrym lesie. „Opole”, nr 3, s. 26-27 [recenzja].

Papuzińska, Joanna, Mała Guliweriada. „Nowe Książki” 1977, nr 1, s. 21-22 [recenzja]. Skutnik, Tadeusz (1977). Żakiewiczowe dzieciom pisanie. „Głos Wybrzeża”, nr 73, s. 5 [recenzja].

Żurakowski, Bogusław (1977). Baśń dla dorosłych i dzieci. „Tygodnik Kulturalny”, nr 6, s. 11 [recenzja].

Borkowska, Ewa (1978). Spóźniony debiut. „Czas”, nr 24, s. 26 [recenzja].

Czermińska, Małgorzata (1978). Dom w autobiografii i powieści o dzieciństwie. W: Michał Głowiński i Aleksandra Okopień-Sławińska (red.). Przestrzeń i literatura. Wrocław: Zakład Narodowy im. Ossolińskich, s. 229-252.

Czyż, Jolanta (1978). Książka tygodnia. „Dziennik Bałtycki”, nr 108, s. 5 [recenzja].

Dybciak, Krzysztof (1978). Świadomość bycia i to, co je wypetnia. „Twórczość”, nr 5, s. 144-147 [recenzja].

Gostkowski, Stanisław (1978). Powieść niesamowita. „Nowy Wyraz”, nr 5, s. 117-120 [recenzja].

Kolbuszewski, Jacek (1978). Zbigniew Żakiewicz. Czteropalcy. Opowieść niesamowita. „Wierchy”, s. 301-302 [recenzja].

Krzysztoszek, Wiesław (1978). Warkocz z pięciu palców. „Miesięcznik Literacki”, nr 4, s. 126-127 [recenzja].

Łukasiewicz, Jacek (1978). Jego NN. „Więź”, nr 1, s. 51-57 [recenzja].

Mędrzycka, Krystyna (1978). „Miastowego ćmoka” wypracowanie z literatury. „Literatura”, nr, 4, s. 14 [recenzja].

Mrozowska, Aldona (1978). Gdańska Książka Roku. „Bibliotekarz Gdański i Elbląski”, nr 3, s. 19-20 [recenzja].

Orski, Mieczysław (1978). Ballada. W: tegoż: Etos lumpa: szkice literackie. Wrocław: Zakład Narodowy im. Ossolińskich, s. 91-92 [recenzja].

Orski, Mieczysław (1978). Mały paluch genetyczny. „Twórczość”, nr 8, s. 126-127 [recenzja].

Pieczara, Marek (1978). Dziennik pisarza. „Nowe Książki”, nr 12, s. 46-47 [recenzja]. Skutnik, Tadeusz (1978). Żakiewicz potrójnie. „Fakty”, nr 31, s. 7 [recenzja]. 
Sznajder, Mirosław (1978). Złota rączka. „Nowe Książki”, nr 6, s. 15-16 [recenzja].

Termer, Janusz (1978). „Miron Białoszewski debiutował...” (Rubryka Współczesna proza polska). „Polonistyka”, nr 4, s. 273-274 [recenzja].

Woźniak, Marzena (1978). Wnętrze człowieka myślącego. „Punkt”, nr 4, s. 166-168 [recenzja].

Zawistowski, Władysław (1978). Niesamowitość i lęk. „Nadodrze”, nr 14, s. 8 [recenzja].

Lechnowicz, Józef (1979). Dziennik intymny mojego N.N. „W drodze”, nr 1, s. 96-101 [recenzja].

Wiśniewska, Ewa T. (1979). „Uczulcie swe zmysły na dziwności natury”. „Nowe Książki”, nr 24, s. 35 [recenzja].

Brzoza, Elżbieta (1981). Bukiet czasu kryzysu. „Nowe Książki”, nr 20, s. 68-70 [recenzja].

Nowicki, Krzysztof (1981). Poemat proza. W: tegoż: Dziennik krytyczny. Gdańsk: Krajowa Agencja Wydawnicza, s. 217-219 [recenzja].

Nowicki, Krzysztof (1981). Rodzaj intymności. W: Nowicki, Krzysztof. Dziennik krytyczny. Gdańsk: Krajowa Agencja Wydawnicza, s. 220-222 [recenzja].

Axentowicz, Medard (1983). Atak z marszu. „Rzeczywistość”, nr 44, s. 4.

Bugajski, Leszek (1983). „Zbigniew Żakiewicz jest.. ”. (Rubryka Między książkami). „Życie Literackie”, nr 28, s. 15 [recenzja].

Mal'dzis, Adam (1983). Wilcze łąki. „Literatura i Mastactwa”, nr 44 (Mińsk) [recenzja].

Nowicki, Krzysztof (1983). Odzyskane źródła. „Fakty”, nr 39, s. 9 [recenzja].

Rogatko, Bogdan (1983). Ocalenie. „Twórczość”, nr 12, s. 133-135 [recenzja].

Suchanek, Lucjan (1983). Wilcze łąki, których nie ma. „Tygodnik Powszechny”, nr 40, s. 5 [recenzja].

Termer, Janusz (1983). „Powoli, ze względu...” (Rubryka Współczesna proza polska). „Polonistyka”, nr 9, s. 815-818 [recenzja].

Wach, Tomasz (1983). Czas utracony. „Nowe Książki”, nr 7, s. 81-82 [recenzja].

Woroszylski, Wiktor (1983). Zakosami, zakolami...: zapiski z kwartalnym opóźnieniem. „Więź”, nr 7, s. 177-180.

Czermińska, Małgorzata (1984). Autobiografizm w twórczości Zbigniewa Żakiewicza. „W kręgu książki”, nr 1, s. 56-63.

Danilczyk, Halina (1984). Dziwotwory. „Tygodnik Kulturalny”, nr 5, s. 12 [recenzja].

Ojcewicz, Grzegorz (1984). I ta dusza po polsku płacze. „Pomerania”, nr 2, s. 24-25 [recenzja].

Wierciński, Adam (1984). Wtajemniczenia. „Opole”, nr 2, s. 20-23 [recenzja].

Łukasiewicz, Jacek (1984). Łąki dzieciństwa. „Odra”, nr 1, s. 99-100 [recenzja].

Antoniewicz, Grażyna (1985). Bajki cudowne, bajki czarowne opowiadała mi niania siwa... „Głos Wybrzeża”, nr 126, s. 4 [recenzja].

Czermińska, Małgorzata (1986). Autobiografizm w twórczości Róży Ostrowskiej i Zbigniewa Żakiewicza. W: Andrzej Bukowski (red.). Literatura gdańska i ziemi gdańskiej po roku 1945. Gdańsk: Wydawnictwo Morskie, s. 143-157.

Szewc, Piotr (1986). Ogniwo mitu. „Znak”, nr 2-3, s. 253-255.

Ejdziukiewicz, Anna (1987). Antynomiczna wizja świata w prozie Zbigniewa Żakiewicza: (cykl powieści poetyckich). „Gdański Rocznik Kulturalny”, t. 10, s. 16-28. 
Skotnicka, Gertruda (1987). Zbigniewa Żakiewicza utwory dla dzieci. „Gdański Rocznik Kulturalny", t. 10, s. 29-39 [recenzja].

Żyłko, Bogusław (1987). Żakiewicz - rusycysta. „Gdański Rocznik Kulturalny”, t. 10, s. $40-46$.

Adamiec, Marek (1988). U nas na Kaszubach ludzie bywają różni. „Res Publica”, nr 8, s. 115-116 [recenzja].

Bąk, Zbigniew (1988). „Gorzkiej wody życia zakosztować...”. „Kwartalnik Nauczyciela Opolskiego", nr 4, s. 185-187 [recenzja].

Bieńkowski, Zbigniew (1988). Dziennik pisarza. Cykl Poezja i niepoezja. „Tygodnik Kulturalny", nr 44, s. 12 [recenzja].

Bugajski, Leszek (1988). „Opowieść o wiernym pająku”. „Życie Literackie”, nr 35, s. 15 [recenzja].

Bugajski, Leszek (1988). Świat i sen o świecie. W: tegoż. W gąszczu znaczeń, Kraków: Krajowa Agencja Wydawnicza, s. 129-135.

Fac, Bolesław (1988). Oswajanie z pięknem Kaszub. „Gwiazda Morza”, nr 8, s. 6 [recenzja].

Gostkowski, Stanisław (1988). Wilno i Kaszuby w „Ciotuleńce” Żakiewicza. „Autograf”, nr 4, s. 62-64 [recenzja].

Isakiewicz, Lech (1988). Ach, te podróże. „Nowe Książki”, nr 4, s. $42-44$ [recenzja].

Isakiewicz, Lech (1988). Od magii do miłości. „Nowe Książki”, nr 10, s. 32-34 [recenzja].

Kietrys, Alina (1988). Ciotuleńka. „Głos Wybrzeża”, nr 86, dod. „Delta”, nr 58, s. 2 [recenzja].

Ojcewicz, Grzegorz (1988). Żyj teraz! „Pomerania”, nr 11, s. 39-40 [recenzja].

Orski, Mieczysław (1988). Kaszuby podszyte Wilnem. „Opole”, nr 12, s. 20 [recenzja].

Czapczyk, Jolanta (1989). Zawód - myślenie. „Przewodnik Katolicki”, nr 3, s. 8 [recenzja].

Drawicz, Andrzej (1989). Pożądanie Wzgórz Wiekuistych. „Powściągliwość i Praca”, nr 6-7, s. 4 [recenzja].

Ojcewicz, Grzegorz (1989). Gdy prosta jest tylko droga życia. „Pomerania”, nr 7-8, s. 55 [recenzja].

Żurakowski, Bogusław (1989). Dorastanie do mitu: o twórczości dla dzieci Zbigniewa Żakiewicza. „Sztuka dla Dziecka”, nr 2, s. 20-21 [recenzja].

Czermińska, Małgorzata (1991). Kresowe korzenie, „Tytuł”, nr 1, s. 119-124.

Żurakowski, Bogusław (1991). Ślady Guliwera w Plimplańskim lesie. „Guliwer”, nr 1, s. 48-53 [recenzja].

Borkowska, Ewa (1992). Książki, książki... „Gazeta Wyborcza”, nr 114, dod. „Gazeta Morska”, nr 133, s. III [nota].

Bratkowski, Piotr (1992). Czas zatrzymany. „Gazeta Wyborcza”, nr 186, s. 17 [recenzja].

Czermińska, Małgorzata (1992). Temat kresowy w prozie powojennej. „Polonistyka”, nr 10, s. 581-588 [recenzja].

Gosk, Hanna (1992). Dusza, która pamięta... „Nowe Książki”, nr 10, s. 42-43 [recenzja]. 
Adamiec, Marek (1993). „I nigdy już nie mieliśmy powrócić nad rzekę...”. „Tytuł”, nr 4, s. $72-77$ [recenzja].

Adamiec, Marek (1993). Wydarty Wilii. „Ex Libris”, nr 31, s. 9-10 [recenzja].

Bagłajewski, Arkadiusz (1993). Co dalej? „Tytuł”, nr 4, s. 65-71.

Błażejewski, Michał (1993). Kresy. W: tegoż: Stereotypy Ziemiomorza w wybranych powieściach pisarzy Wybrzeża Gdańskiego. Gdańsk: Wydawnictwo Uniwersytetu Gdańskiego.

Czermińska, Małgorzata (1993). Autobiografia duchowa $w$ dwudziestowiecznej literaturze polskiej. W: M. Jasińska-Wojtkowska, K. Dybciak (red.). Religijne tradycje literatury polskiej. T. 3: Proza polska $w$ kręgu religijnych inspiracji. Lublin: Wydawnictwo Towarzystwa Naukowego KUL.

Hadaczek, Bolesław (1993). Kresowość Zbigniewa Żakiewicza. W: Hadaczek, Bolesław. Kresy w literaturze polskiej XX wieku: szkice. Szczecin: Ottonianum, s. 95-104.

Huelle, Paweł (1993). Opowiedz im rzeczy. „Tytuł”, nr 4, s. 78-81.

Łukasiewicz, Jacek (1993). Niepowrotność. „Tygodnik Powszechny”, nr 46, s. 10 [recenzja].

Orski, Mieczysław (1993). O tym, co „jak zdrowie”. „Słowo Polskie”, nr 17.

Tomaszewski, Marek (1993). Tropem wilka wyjącego „po wołczemu”, czyli oniryczna wizja przyrody w powieściach Zbigniewa Żakiewicza. „Kresy”, nr 14, s. 244-247.

Bieńkowski, Zbigniew (1994). Kresy, tygiel pamięci. „Nowe Książki”, nr 3, s. 10-11 [recenzja].

Termer, Janusz (1994). Między Arkadią a Piekłem. „Twórczość”, nr 3, s. 119-120 [recenzja].

Adamiec, Marek (1995). Swój jestem, Wołczacki... W: Adamiec, Marek. Bez namaszczenia, Lublin: Stowarzyszenie Literackie „Kresy”, s. 152-156.

Nowicki, Krzysztof (1995). Do Zbigniewa Żakiewicza. „Topos”, nr 5-6, s. 22-23.

Tomaszewski, Marek (1995). „Pan Tadeusz” à rebours, czyli nowe wcielenie litewsko-białoruskiej przyrody w polskiej prozie po 1970 r. „Teksty Drugie”, nr 2, s. 178-192.

Waśkiewicz, Andrzej K. (1995). Obroty wiernej pamięci. „Akcent”, nr 2, s. 150-153 [recenzja].

Żakiewicz, Maciej (1995). Tatarski ród Oganowskich $w$ tradycji gdańskiej rodziny $\dot{Z} a-$ kiewiczów. „Rocznik Tatarów Polskich”, t. 3, s. 195-204.

Dobosz, Henryka (1996). Wszystkie rzeki wpadaja do morza..., rozmowa ze Zbigniewem Żakiewiczem. „Tytuł”, nr specjalny - 4: Rozmowy „Tytułu” (red. Krystyna Chwin).

Jęsiak, Anna (1996). Zbigniew Żakiewicz, rozmowa ze Zbigniewem Żakiewiczem. „Dziennik Bałtycki”, nr 168 z dn. 19. 07. 1996, dod. „Rejsy”, s. 8-9.

Kietrys, Alina (1996). Uchwycić czas, rozmowa ze Zbigniewem Żakiewiczem. „Głos Wybrzeża” nr 117 z dn. 31.05.-02.06.1996.

Klecel, Marek (1996). Krzepienie serc. „Słowo”, nr 168, s. 16 [recenzja].

Klecel, Marek (1996). Pobożność wobec istnienia. „Sycyna” nr 20, s. 17 [recenzja].

Konończuk, Elżbieta (1996). Opowieści Zbigniewa Żakiewicza o czasie prawie minionym, [w:] Wilno i Kresy Północno-Wschodnie. Materiały II Międzynarodowej Konferencji w Białymstoku 14-17 IX 1994 r. w czterech tomach. T. 4: Literatura. Elżbieta Feliksiak i Anna Kieżuń (red.). Białystok: Towarzystwo Literackie im. Adama Mic- 
kiewicza. Oddział Białostocki - Zakład Teorii i Antropologii Literatury w Instytucie Filologii Polskiej. Filia Uniwersytetu Warszawskiego w Białymstoku.

Koźmiński, Leszek M. (1996). Z zaścianka ku Uniwersum. „Kresy”, nr 4, s. 161-162 [recenzja].

Pawelec, Dariusz (1996). Wrzeszcz i okolice. „Nowe Książki”, nr 8, s. 16 [recenzja].

Szewc, Piotr (1996). Eseje kresowe: literackie ścieżki po stegnach i ogrodach. „Życie Warszawy", nr 119, s. 7 [recenzja].

Ubertowska, Aleksandra (1996). Notatnik liryczny. „Gazeta Wyborcza”, nr 121, dod. „Gazeta Morska”, s. 4 [recenzja].

Wszystkie rzeki wpadaja do morza... Ze Zbigniewem Żakiewiczem rozmawia Henryka Dobosz. W: Żakiewicz, Zbigniew. Ujrzane, w czasie zatrzymane. Biblioteka „Tytułu”. Gdańsk: Marabut 1996, s. 26-56.

Zalesiński, Jarosław (1996). Pudło z pocztówkami. „Gwiazda Morza”, nr 13, s. 22 [recenzja].

Adamiec, Marek (1997). Z wędrówki. „Twórczość”, nr 1, s. 104-107 [recenzja].

Czapliński, Przemysław (1997). Sielanka metafizyczna. „Tytuł”, nr 2, s. 153-158.

Czapliński, Przemysław (1997). Ślady przełomu: o prozie polskiej 1976-1996. Kraków: Wydawnictwo Literackie, s. 233-237 i in.

Kalinowski, Grzegorz (1997). Rozpraszanie mroku. „Kwartalnik Artystyczny”, nr 1, s. $137-138$ [recenzja].

Orski, Mieczysław (1997). Żakiewicz w czasie zatrzymuje. „Przegląd Powszechny”, nr 2, s. 245-247 [recenzja].

Papuzińska, Joanna (1997). Dziwne jest morze. „Guliwer”, nr 3, s. 27-28.

Czerska, Tatiana (1998). Pozostać dzieckiem: o grotesce w powieściach Czesława Miłosza, Zbigniewa Żakiewicza i Stanisława Srokowskiego. „Zeszyty Naukowe, Szczecińskie Prace Polonistyczne / Uniwersytet Szczeciński”, nr 10, s. 25-44.

Huelle, Paweł (1998). Sycowa Huta. (Cykl „Imiona, miejsca...”). „Gazeta Wyborcza”, nr 185 , s. 8 .

Tomaszewski, Marek (1998). Tropem wilka wyjacego „po wołczemu”, czyli oniryczna wizja przyrody w powieściach Zbigniewa Żakiewicza. W: tegoż: Od chaosu do kosmosu: szkice o literaturze polskiej i francuskiej XX wieku. Seria Badania Polonistyczne za granicą. T. 2 (red. W. Sołecki i in.). Warszawa: IBL PAN.

Tomaszewski, Marek (1998). „Pan Tadeusz” à rebours, czyli nowe wcielenie litewsko-białoruskiej przyrody w polskiej prozie po 1970 r. W: tegoż: Od chaosu do kosmosu: szkice o literaturze polskiej i francuskiej XX wieku. Seria Badania Polonistyczne za granicą. T. 2. Warszawa: IBL Wydawnictwo, s. 156-166.

Czermińska, Małgorzata (1999). Przemiany tematu kresowego: idylla, tragizm, groteska w powieściach autobiograficznych Zbigniewa Żakiewicza. „Tytuł”, nr 1, s. 155-165.

Czerska, Tatiana (1999). Dzieciństwo czy przekleństwo? Pierwiastki oniryczne w prozie Zbigniewa Żakiewicza. W: Glatzel, Ilona, Smólski, Jerzy i Sobolewska, Anna (red.). Oniryczne tematy i konwencje w literaturze polskiej w XX wieku. Toruń: Wydawnictwo Uniwersytetu Mikołaja Kopernika, s. 283-295.

Czerska, Tatiana (1999). Topos dzieciństwa w utworach Zbigniewa Żakiewicza. „Zeszyty Naukowe, Szczecińskie Prace Polonistyczne / Uniwersytet Szczeciński”, nr 11, s. $81-101$. 
Hadaczek, Bolesław (1999). Dominanty strukturalne literatury kresowej. „Zeszyty Naukowe, Szczecińskie Prace Polonistyczne / Uniwersytet Szczeciński”, nr 11, s. 5-24. Huelle, Paweł (1999). Drogi Zbyszku: mowa na cześć Zbigniewa Żakiewicza. „Tytuł”, nr 1, s. 166-169.

Huelle, Paweł (1999). Soplica, Żakiewicz, Oganowski, cykl „Imiona, miejsca...”. „Gazeta Wyborcza”, nr 265, s. 17.

Klimek, Anna (1999). Powrót do nieznanej Arkadii: autobiografizm w prozie Zbigniewa Żakiewicza i Włodzimierza Paźniewskiego. „Zeszyty Naukowe Filologii Polskiej I Uniwersytet Opolski”, z. 39, s. 101-109.

Czermińska, Małgorzata (2000). Autobiografia duchowa w dwudziestowiecznej literaturze polskiej. W: tejże: Autobiograficzny trójkąt: świadectwo wyznanie i wyzwanie. Kraków: Universitas, s. 55-99.

Czermińska, Małgorzata (2000). Przemiany tematu kresowego w powieści autobiograficznej - spiżarnie pamięci. W: tejże: Autobiograficzny trójkąt: świadectwo wyznanie i wyzwanie. Kraków: Universitas, s. 117-135.

Czerska, Tatiana (2000). „Ja” autobiograficzne i jego sobowtór w prozie Zbigniewa Żakiewicza. W: Katarzyna R. Łozowska i Ewa Tierling (red.). Literackie Kresy i bezkresy: ksiega ofiarowana Profesorowi Bolesławowi Hadaczkowi. Szczecin: Wydawnictwo Naukowe Uniwersytetu Szczecińskiego, s. 247-259.

Czerska, Tatiana (2000). Kosmologia Zbigniewa Żakiewicza. „Zeszyty Naukowe, Szczecińskie Prace Polonistyczne / Uniwersytet Szczeciński”, nr 12, s. 57-69.

Czerska, Tatiana (2000). Tęsknoty i powroty. „Pogranicza”, nr 6, s. 109-110.

Górski, Krzysztof (2000). Kaszuby i Kresy, „Gazeta Wyborcza”, nr 213, dod. „Gazeta Morska”, nr 213, s. 8 [recenzja].

Jurewicz, Aleksander (2000). Maj, czerwiec 2000. Cykl Zapiski ze stróżówki (8). „Kwartalnik Artystyczny", nr 3, s. 150-153.

Łukasiewicz, Jacek (2000). Zobaczone, zatrzymane...: z listy lektur. „Arkusz”, nr 6, s. 8-9 [recenzja].

Mamoń, Bronisław (2000). Zdziwienie, poznanie... „Tygodnik Powszechny”, nr 46, s. 15.

Orski, Mieczysław (2000). Gorycz i sól morza. „Przegląd Powszechny”, nr 10, s. 126-129 [recenzja].

Skutnik, Tadeusz (2000). Wśród serdecznych przyjaciół...: nowa książka Zbigniewa Żakiewicza. „Dziennik Bałtycki”, nr 133, s. 15.

Termer, Janusz (2000). List do Zbigniewa Żakiewicza - zamiast recenzji z „Goryczy i soli morza”. „Autograf”, nr 4, s. 35.

W tkaninie czasu ukryte. Ze Zbigniewem Żakiewiczem o literaturze i jej pograniczach rozmawiaja Aneta Krawczyk i Piotr W. Lorkowski (2000). „Topos”, nr 3-4, s. 157.

Mizerkiewicz, Tomasz (2001). Zamiast stylizacji mitycznej - „Ród Abaczów” Zbigniewa Żakiewicza. W: Mizerkiewicz, Tomasz. Stylizacje mityczne w prozie polskiej po 1968 roku. Seria Biblioteka Literacka „Poznańskich Studiów Polonistycznych”. T. 33. Poznań, s. 173-183.

Orski, Mieczysław (2001). „Jedną z ostatnich pozycji...” „Odra”, nr 2, s. 120-121 [recenzja]. 
Sowińska, Renata (2001). „Między mięsistością krajobrazu a metafizyczną otwartościa morza”. „Twórczość”, nr 11, s. 90-92.

Czerska, Tatiana (2002). Dziecięce przė̇ycie sacrum w prozie Zbigniewa Żakiewicza. „Zeszyty Naukowe, Szczecińskie Prace Polonistyczne / Uniwersytet Szczeciński”, nr 13, s. 63-87.

Czerska, Tatiana (2003). Między Wileńszczyzną a Kaszubami: o twórczości Zbigniewa Żakiewicza w latach 1990-2000. W: Cieślak, Tomasz i Pietrych, Krystyna (red.). Literatura polska 1990-2000. T. 2. Kraków: Zielona Sowa, s. 237-249.

Czerska, Tatiana (2003). Sacrum i eros $w$ prozie Zbigniewa Żakiewicza. „Zeszyty Naukowe / Uniwersytet Szczeciński, nr 356. Szczecińskie Prace Polonistyczne”, nr 14, s. 97-111.

Hadaczek, Bolesław (2003). Kresowość Zbigniewa Żakiewicza. W: tegoż: Małe ojczyzny kresowe w literaturze polskiej XX wieku. Szkice. Szczecin: Wydawnictwo „PoNaD”, s. 80-89.

Adamiec, Marek (2004). Żubr na Pomorzu: słów kilka o twórczości Zbigniewa Żakiewicza. W: Arendt, Teresa, Turo, Krystyna (red.). Literatura Wybrzeża po 1980 roku. Materiały z sesji naukowej Gdynia 3-4 grudnia 2003. Pelplin: Wydawnictwo Diecezji Pelplińskiej „Bernardinum”, s. 178-187.

Czerska, Tatiana (2005). Gra o tożsamość. Dylematy wielokulturowości w prozie Zbigniewa Żakiewicza. W: Drong, Leszek i Kalaga, Wojciech (red.). Wielokulturowość. Postulat i praktyka. Katowice: Wydawnictwo Uniwersytetu Śląskiego.

Czerska, Tatiana (2005). Uchwycić słowem świat widzialny: sensualizm w prozie Zbigniewa Żakiewicza. W: Kresy i pogranicze w literaturze. Zeszyty Naukowe, nr 381 Szczecińskie Prace Polonistyczne, nr 15, Szczecin.

Czerska, Tatiana (2006). Mityzacja - groteska - wyznanie: taktyka autobiograficzna w prozie Zbigniewa Żakiewicza. W: Gontarz, Beata i Krakowiak, Małgorzata (red.). Świat przez pryzmat ja. T. 1: Teorie i autobiograficzne rekonesanse. Katowice: Wydawnictwo Agencja Artystyczna Para, s. 155-166.

Czerska, Tatiana (2006). Ocalić ład istnienia?: sakralizacja codzienności w literaturze Kresów: Miłosz, Konwicki, Żakiewicz. W: Dopart, Bogusław (red.). „Pan Tadeusz” i jego dziedzictwo: recepcja. Kraków: Universitas, s. 221-235.

Czerska, Tatiana (2006). Tam, gdzie wilcze łąki, Niżany i kniaziowskie draje...: Zbigniewa Żakiewicza podróż do ogrodów pamięci. „Autograf Post”, nr 6, s. 14-16.

Jurewicz, Aleksander (2006). Zbigniew Żakiewicz w „Bibliotece Gdańskiej”. „Topos”, nr 3, s. 155-157.

Orski, Mieczysław (2006). Uroda i gorycz przeszłości. „Przegląd Powszechny”, nr 6, s. 149-152 [recenzja].

Żyłko, Bogusław (2006). Trylogia kresów Zbigniewa Żakiewicza. „Kwartalnik Artystyczny", nr 2, s. 237-240 [recenzja].

Dęboróg-Bylczyński, Maciej (2007). W zakolu Wilii. „Pomerania”, nr 7-8, s. 75-76 [recenzja].

Huelle, Paweł (2007). Droga, czyli put'. „Rzeczpospolita”, nr 53, dod. „Plus Minus Rzecz o Książkach”, s. 16 [recenzja].

Klimowicz, Tadeusz (2007). Pamięci przemów. „Przegląd Polityczny”, nr 83, s. 150-152 [recenzja]. 
Pamięć - istota zakorzenienia: z pisarzem Zbigniewem Żakiewiczem rozmawia Maciej Dęboróg-Bylczyński (2007). „Pomerania”, nr 7-8, s. 36-37.

Pomorski, Adam (2007). Rosja, ale jaka. „Kwartalnik Artystyczny”, nr 3, s. 179-184 [recenzja].

Żyłko, Bogusław (2007). Rosja, dawne kresy i Polska. „Odra”, nr 6, s. 110-112 [recenzja].

Taylor-Terlecka, Nina (2008). Miśs smorgończyk - Mistrz z Mołodeczna. „Przegląd Polski", nr 33.

Goczoł, Jan (2010). Tarnica: na szlakach i ścieżkach ze Zbigniewem Żakiewiczem. "Strony” (Opole), nr 6, s. 78-80.

Ojcewicz, Grzegorz (2010). Jaka jesteś, Rosjo. „Acta Polono-Ruthenica”, t. XV, s. 281-287.

Skutnik, Tadeusz (2010). Chłopiec o lisiej twarzy. „Dziennik Bałtycki”, nr 152, dod. „Rejsy", $\mathrm{nr} 132, \mathrm{z}$ dn. 2.07.2010, s. 21 [recenzja].

Skutnik, Tadeusz (2010). Kochat życie pod wszelkimi postaciami. „Gazeta Wyborcza” 06.07.2010 [online].

Skutnik, Tadeusz (2010). Wczoraj odszedł od nas Zbigniew Żakiewicz. „Dziennik Bałtycki", nr 146, s. 2.

Wachcińska, Olga (2010). „Wołk-Wołczacki jestem i koniec”: o poszukiwaniu tożsamości w powieści „Wilcze Łąki” Zbigniewa Żakiewicz. „Tekstura: Rocznik Filologiczno-Kulturoznawczy", t. 1, red. V. Wróblewska Torun.

Wierciński, Adam (2010). Żubr litewski: o Zbigniewie Żakiewiczu. „Strony” (Opole), nr 6, s. 82-83.

Załuski, Stanisław (2010). Pożegnanie wileńskiego tura. „Riviera”, nr 6, s. 10-11.

Żurakowski, Bogusław (2010). Z Opola do Gdańska. „Strony” (Opole), nr 6, s. 74-77.

Czerska, Tatiana (2012). Kobiety (u) Żakiewicza. W: Czerska, Tatiana i Łozowska, Renata Katarzyna (red.). Czytanie Żakiewicza. Szczecin: Wydawnictwo Zapol, s. 79-89.

Czerska, Tatiana (2012), „Literatura była sposobem, by się z tym wszystkim rozprawić...” (Ze Zbigniewem Żakiewiczem rozmawia Tatiana Czerska. W: Czerska, Tatiana i Łozowska, Renata Katarzyna (red.). Czytanie Żakiewicza. Szczecin: Wydawnictwo Zapol, s. 115-124.

Dęboróg-Bylczyński, Maciej (2012). „Tutejsi” na „tutejszczyźnie”: o przestrzeni i społeczności kresowej w trzech wileńskich powieściach Zbigniewa Żakiewicza. W: Tatiana Czerska i Renata Katarzyna Łozowska (red.). Czytanie Żakiewicza. Szczecin: Wydawnictwo Zapol, s. 61-77.

Dutka, Elżbieta (2012). Przełamywanie melancholii w opowieściach Zbigniewa Żakiewicza („Ciotuleńka”, „Gorycz i sól morza”). W: Tatiana Czerska i Renata Katarzyna Łozowska (red.). Czytanie Żakiewicza. Szczecin: Wydawnictwo Zapol, s. 7-26.

Iwańska, Ewelina (2012). Umóm Rossiju nie poniat'... Obraz Rosji w utworze Zbigniew Żakiewicza. W: Tatiana Czerska i Renata Katarzyna Łozowska (red.). Czytanie Żakiewicza. Szczecin: Wydawnictwo Zapol, s. 101-110.

„Rosja, Rosja...” (2012). W: Czerska, Tatiana, Łozowska, Renata Katarzyna (red.). Czytanie Żakiewicza. Szczecin: Wydawnictwo Zapol, s. 101-110. 
Żakiewicz, Maciej (2012). Odbicie Marca 1968 i Grudnia 1970 roku w biografii Zbigniewa Żakiewicza. W: Czerska, Tatiana i Łozowska, Renata Katarzyna (red.). Czytanie Żakiewicza. Szczecin: Wydawnictwo Zapol, s. 113-114.

Żyłko Bogusław, Podróż(e) na Kresy ze Zbigniewem Żakiewiczem. „Odra” 2012, nr 6, s. $37-45$.

Apanowicz, Franciszek (2015). Zbigniew Żakiewicz - rusycysta. Uwagi i wspomnienia w piątą rocznicę śmierci. „Studia Rossica Gedanensia”, t. 2 (Gdańsk), s. 513-523.

Czermińska, Małgorzata (2015). Żakiewicz jeden a dwoisty (wspomnienie). „Studia Rossica Gedanensia”, t. 2 (Gdańsk), s. 537-539.

Ojcewicz, Grzegorz (2015). Jaka jesteś, Rosjo. „Studia Rossica Gedanensia”, t. 2 (Gdańsk), s. 547-552.

Ojcewicz, Grzegorz (2015). Kwadrat Zbigniewa Żakiewicza. „Studia Rossica Gedanensia”, t. 2 (Gdańsk), s. 540-552.

Żyłko, Bogusław 2015 (). Podróż(e) na Kresy ze Zbigniewem Żakiewiczem. „Studia Rossica Gedanensia”, t. 2 (Gdańsk), s. 524-536.

Apanowicz, Franciszek (2017). Moje spotkania ze Zbigniewem Żakiewiczem - Pisarzem, Nauczycielem, Człowiekiem. W: Wojan, Katarzyna (red.). W czasie zatrzymane. T. 2: Ze Zbigniewem Żakiewiczem na Kresach i w bezkresie. Seria Biblioteka „Studia Rossica Gedanensia”. Gdańsk: Wydawnictwo Uniwersytetu Gdańskiego, s. 75-104.

Chojnacki, Hieronim (2017). Wątki religijno-duchowe w szkicach literackich $z$ lat 1977-2008, Zbigniewa Żakiewicza. W: Wojan, Katarzyna (red.). W czasie zatrzymane. T. 2: Ze Zbigniewem Żakiewiczem na Kresach i $w$ bezkresie. Seria Biblioteka „Studia Rossica Gedanensia”. Gdańsk: Wydawnictwo Uniwersytetu Gdańskiego, s. 123-138.

Czerska, Tatiana (2017). Fotografie Zbigniewa Żakiewicza - uobecnianie Nieobecnego. W: Wojan, Katarzyna (red.). W czasie zatrzymane. T. 2: Ze Zbigniewem Żakiewiczem na Kresach $i w$ bezkresie. Seria Biblioteka „Studia Rossica Gedanensia”. Gdańsk: Wydawnictwo Uniwersytetu Gdańskiego, s. 27-36.

Czerska, Tatiana (2017). O Zbigniewie Żakiewiczu. W: Katarzyna Wojan (red.). W czasie zatrzymane. T. 2: Ze Zbigniewem Żakiewiczem na Kresach i w bezkresie. Seria Biblioteka Studia Rossica Gedanensia. Gdańsk: Wydawnictwo Uniwersytetu Gdańskiego, s. 11-14.

Czerwiński, Grzegorz (2017). Żakiewicz i Tatarzy: biografia - literatura - etniczność. W: Wojan, Katarzyna (red.). W czasie zatrzymane. T. 2: Ze Zbigniewem Żakiewiczem na Kresach $i$ w bezkresie. Seria Biblioteka „Studia Rossica Gedanensia”. Gdańsk: Wydawnictwo Uniwersytetu Gdańskiego, s. 35-44.

Fijałkowska-Janiak, Irena (2017). Zbyszek Żakiewicz - mój Nauczyciel. W: Wojan, Katarzyna (red.). W czasie zatrzymane. T. 2: Ze Zbigniewem Żakiewiczem na Kresach $i$ w bezkresie. Seria Biblioteka „Studia Rossica Gedanensia”. Gdańsk: Wydawnictwo Uniwersytetu Gdańskiego, s. 105-114.

Kaźmierczyk, Zbigniew (2017). Miłosza i Żakiewicza manichejski klucz do Rosji. W: Wojan, Katarzyna (red.). W czasie zatrzymane. T. 2: Ze Zbigniewem Żakiewiczem na Kresach $i$ w bezkresie. Seria Biblioteka "Studia Rossica Gedanensia”. Gdańsk: Wydawnictwo Uniwersytetu Gdańskiego, s. 45-58. 
Koprowski, Piotr (2017). Pamięć i lektura. Kilka refleksji na kanwie szkiców literackich Zbigniewa Żakiewicza. W: Wojan, Katarzyna (red.). W czasie zatrzymane. T. 2: Ze Zbigniewem Żakiewiczem na Kresach i w bezkresie. Seria Biblioteka „Studia Rossica Gedanensia”. Gdańsk: Wydawnictwo Uniwersytetu Gdańskiego, s. 59-66.

Lauer, Wiesław ks. (2017). Zbigniew Żakiewicz - piewca Bożego Miłosierdzia. W: Wojan, Katarzyna (red.). W czasie zatrzymane. T. 2: Ze Zbigniewem Żakiewiczem na Kresach i w bezkresie. Seria Biblioteka „Studia Rossica Gedanensia”. Gdańsk: Wydawnictwo Uniwersytetu Gdańskiego, s. 139-162.

Legeżyńska, Anna (2017). Odnawianie „Tryptyku wileńskiego” Zbigniewa Żakiewicza. W: Baranow, Andrzej i Ławski, Jarosław (red.). Zagadnienia bilingwizmu. Seria I: Dwujęzyczny pisarze litewscy i polscy. Colloquia Orientalia Bialostocensia, nr 27. Białystok-Wilno: Uniwersytet w Białymstoku - Książnica Podlaska im. Łukasza Górnickiego, s. 415-432.

Nowosielski, Kazimierz (2017). Zbigniew Żakiewicz i jego N.N. W: Wojan, Katarzyna (red.). W czasie zatrzymane. T. 2: Ze Zbigniewem Żakiewiczem na Kresach $i$ w bezkresie. Seria Biblioteka „Studia Rossica Gedanensia”. Gdańsk: Wydawnictwo Uniwersytetu Gdańskiego, s. 67-74.

Ojcewicz, Grzegorz (2017). Szczęśliwi, którzy pożądaja Wzgórz Wiekuistych. W: Wojan, Katarzyna (red.). W czasie zatrzymane. T. 2: Ze Zbigniewem Żakiewiczem na Kresach i w bezkresie. Seria Biblioteka „Studia Rossica Gedanensia”. Gdańsk: Wydawnictwo Uniwersytetu Gdańskiego, s. 115-122.

Taylor-Terlecka Nina (2017). Miś smorgończyk - Mistrz z Mołodeczna. W: Żakiewicz, Zbigniew. W czasie zatrzymane. T. 1: Wybór szkiców literackich z lat 1977-2008. Zebrał Maciej Żakiewicz. Oprac. naukowo oraz wstępem opatrzyła Katarzyna Wojan. Seria „Studia Rossica Gedanensia”. Gdańsk: Wydawnictwo Uniwersytetu Gdańskiego, s. 17-20.

Żakiewicz, Maciej (2017). O związkach rodzinnych Zbigniewa Żakiewicza z pogórzańska wsia Kobylanka koło Gorlic. W: Wojan, Katarzyna (red.). W czasie zatrzymane. T. 2: Ze Zbigniewem Żakiewiczem na Kresach $i$ w bezkresie. Seria Biblioteka „Studia Rossica Gedanensia”. Gdańsk: Wydawnictwo Uniwersytetu Gdańskiego, s. $163-170$.

Żakiewicz, Maciej (2017). Powrócić do Wilna. O malarstwie Eugeniusza Kazimirowskiego. W: Wojan, Katarzyna (red.). W czasie zatrzymane. T. 2: Ze Zbigniewem Żakiewiczem na Kresach i w bezkresie. Seria Biblioteka „Studia Rossica Gedanensia”. Gdańsk: Wydawnictwo Uniwersytetu Gdańskiego, s. 171-174.

Żyłko, Bogusław (2017). Wyobraźnia przestrzenna Zbigniewa Żakiewicza. W: Wojan, Katarzyna (red.). W czasie zatrzymane. T. 2: Ze Zbigniewem Żakiewiczem na Kresach $i$ w bezkresie. Seria Biblioteka „Studia Rossica Gedanensia”. Gdańsk: Wydawnictwo Uniwersytetu Gdańskiego, s. 15-26.

Dęboróg-Bylczyński, Maciej (b.r.w.). Mowa pamięci - jeszcze o prozie Zbigniewa Żakiewicza. [Online] http://verte.art.pl/literatura/mowapamieci/ (10.08.2018).

Fijałkowska-Janiak, Irena (2018). Im więcej czasu mija od śmierci Zbyszka, tym bardziej odczuwam Jego nieobecność... „Gazeta Uniwersytecka. Pismo Społeczności Akademickiej Uniwersytetu Gdańskiego”. Wydanie specjalne: Zbigniew Żakiewicz. In memoriam. Katarzyna Wojan i Zbigniew Kaźmierczyk (red.), s. 8-10. 
Jurewicz, Aleksander (2018). Pusta ulica Kościuszki. „Gazeta Uniwersytecka. Pismo Społeczności Akademickiej Uniwersytetu Gdańskiego”. Wydanie specjalne: Zbigniew Żakiewicz. In memoriam. Katarzyna Wojan i Zbigniew Kaźmierczyk (red.), s. 11-11.

Kaźmierczyk, Zbigniew (2018). Rosja Żakiewicza. „Gazeta Uniwersytecka. Pismo Społeczności Akademickiej Uniwersytetu Gdańskiego”. Wydanie specjalne: Zbigniew Żakiewicz. In memoriam. Katarzyna Wojan i Zbigniew Kaźmierczyk (red.), s. 14-15.

Kaźmierczyk, Zbigniew i Wojan, Katarzyna (2018). Żakiewicz o Żakiewiczu. Z dr. Maciejem Żakiewiczem rozmawiają; prof. nadzw. dr hab. Katarzyna Wojan oraz prof. nadzw. dr hab. Zbigniew Kaźmierczyk. „Gazeta Uniwersytecka. Pismo Społeczności Akademickiej Uniwersytetu Gdańskiego”. Wydanie specjalne: Zbigniew Żakiewicz. In memoriam. Katarzyna Wojan i Zbigniew Kaźmierczyk (red.), s. 21-26.

Wątróbska, Halina (2018). Moja tajemnica „klucza Zbigniewa Żakiewicza”. „Gazeta Uniwersytecka. Pismo Społeczności Akademickiej Uniwersytetu Gdańskiego”. Wydanie specjalne: Zbigniew Żakiewicz. In memoriam. Katarzyna Wojan i Zbigniew Kaźmierczyk (red.), s. 6-7.

Wojan, Katarzyna (2018). Kilka słów o „W czasie zatrzymane”. „Gazeta Uniwersytecka. Pismo Społeczności Akademickiej Uniwersytetu Gdańskiego”. Wydanie specjalne: Zbigniew Żakiewicz. In memoriam. Katarzyna Wojan i Zbigniew Kaźmierczyk (red.), s. 20-20.

Wojan, Katarzyna (2018). Spotkanie literackie: promocja książek „W czasie zatrzymane” Żakiewicza i o Żakiewiczu. „Gazeta Uniwersytecka. Pismo Społeczności Akademickiej Uniwersytetu Gdańskiego”. Wydanie specjalne: Zbigniew Żakiewicz. In memoriam. Katarzyna Wojan i Zbigniew Kaźmierczyk (red.), s. 18-20.

Wojan, Katarzyna (2018). Wspomnienie: Zbigniew Żakiewicz i Finlandia. „Gazeta Uniwersytecka. Pismo Społeczności Akademickiej Uniwersytetu Gdańskiego”. Wydanie specjalne: Zbigniew Żakiewicz. In memoriam. Katarzyna Wojan i Zbigniew Kaźmierczyk (red.), s. 12-13.

Wojan, Katarzyna (2018). Przekłady Żakiewicza i z Żakiewicza. „Gazeta Uniwersytecka. Pismo Społeczności Akademickiej Uniwersytetu Gdańskiego”. Wydanie specjalne: Zbigniew Żakiewicz. In memoriam. Katarzyna Wojan i Zbigniew Kaźmierczyk (red.), s. 16-17.

Żakiewicz, Maciej (2018). Zbigniew Żakiewicz. „Gazeta Uniwersytecka. Pismo Społeczności Akademickiej Uniwersytetu Gdańskiego”. Wydanie specjalne: Zbigniew Żakiewicz. In memoriam. Katarzyna Wojan i Zbigniew Kaźmierczyk (red.), s. 2-3.

Żyłko, Bogusław (2018). Jak poznałem Zbigniewa Żakiewicza. „Gazeta Uniwersytecka. Pismo Społeczności Akademickiej Uniwersytetu Gdańskiego”. Wydanie specjalne: Zbigniew Żakiewicz. In memoriam. Katarzyna Wojan i Zbigniew Kaźmierczyk (red.), s. 16-17.

\section{Artykuły naukowe opublikowane za granicą}

Панькова, Ольга (2014). Autorefleksja bohatera-narratora w powieści „Dolina Hortensji” Z. Żakiewicza. B: Антропологические сдвиги переломных эпох и их отраже- 
ние в титературе. Ч. 1. Учреждение образования Гродненский гос. ун-т им. Я. Купалы; гл. ред. Т. Е. Автухович. Гродно: ГрГУ им. Я. Купалы, с. 111-115.

Pankowa, Olga (2014). Sytuacja wielojęzycznego pogranicza w powieści „Wilcze Łąki” Zbigniewa Żakiewicza. W: Mączyński, Maciej i Horyn, Ewa (red.). Język w środowisku wiejskim. Kraków: Collegium Columbinum, s. 271-277.

Панькова, Ольга (2014). Время и его символика в романе «Долина Гортензии» Збигнева Жакевича. «Пушкинские чтения». Санкт-Петербург: ЛГУ им. А. С. Пушкина, с. 225-231.

Панькова, Olga (2015). Motyw „słońca, soulca, solnyszka” w przestrzeni lingwokulturowej twórczości Z. Żakiewicza. В: Я. Панькоў и др. (рэд.). Шлях да ўзаемнасиі = Droga ku wzajemnosci: матэрыялы ХХ міжнар. навук. канф., Гродна, 23-24 кастр. 2014 2. Мінск: БудМедыяПраект, с. 82-84.

Pankowa, Olga (2015). Oczekiwanie spełnienia w powieści „Dolina Hortensji” Zbigniewa Żakiewicza. W: Koziara, Stanisław, Młynarczyk, Ewa i Skowronek, Bogusław (red.). Dialog z tradycją. T. 4: Język - komunikacja - kultura. Seria Annales Universitatis Paedagogicae Cracoviensis. Studia Linguistica. Kraków: Collegium Columbinum, s. 256-258.

Панькова, Ольга (2017). Projekcja przeszłości i motyw powrotu w powieści Z. Żakiewicza „Wilcze Łąki”. В: Рэспубліканскія Купалаўскія чытанні: зборнік навук. артыкулаў. Установа адукацыі Гродзенскі дзярж. ун-т імя Я. Купалы. Адказ. рэд.: А. С. Садоўская и др. Гродна: ЮрСаПрынт, с. 279-283.

Pankowa, Olga (2017). Tak jak Trójca nam jedyna. Żakiewiczowskie refleksje nad obyczajowością kresową. W: Mączyński, Maciej, Horyń, Ewa i Zmuda, Ewa (red.). W kręgu dawnej polszczyzny. T. 4. Kraków: Collegium Columbinum, s. 207-220.

\section{Rozprawy doktorskie}

Czerska, Tatiana (2002). Sacrum w twórczości Zbigniewa Żakiewicza. Rozprawa doktorska napisana pod kierunkiem prof. dr hab. Bolesława Hadaczka. Uniwersytet Szczeciński, Szczecin.

\section{Prace dyplomowe}

Kuśnierz, Katarzyna. Pamięć jako kategoria nadrzędna w „Tryptyku wileńskim” Zbigniewa Żakiewicza”. Praca licencjacka przedstawiona na „Seminarium Inspiracje wielokulturowe w polskiej literaturze współczesnej”. Katolicki Uniwersytet Lubelski, Lublin 2012.

\section{Nota wydawnicza}

Wykorzystano materiały bibliograficzne w opracowaniu Leszka Rybickiego zamieszczone na stronie Wojewódzkiej Biblioteki Publicznej w Gdańsku: http://www.old. wbpg.org.pl/slowniklista.php?pisarz=4 (dostęp 2.06.2018). Wyliczone w nich pozycje zostały poddane weryfikacji, dokonano stosownych korekt i uzupełnień.

Niniejszy wykaz publikacji bibliograficznych traktujących o dorobku literaturoznawczym Z. Żakiewicza stanowi nową, poprawioną i zaktualizowną, wersję faktografii bibliograficznej. 